\title{
The Clinical Spectrum of Resistance to Thyroid Hormone Alpha in Children and Adults
}

\author{
(1) ibrahim Mert Erbaş, (1) Korcan Demir \\ Dokuz Eylül University Faculty of Medicine, Department of Pediatric Endocrinology, İmir, Turkey
}

\begin{abstract}
Resistance to thyroid hormone alpha occurs due to pathogenic, heterozygous variants in THRA. The entity was first described in 2012 and to date only a small number of patients with varying severity have been reported. In this review, we summarize and interpret the heterogeneous clinical and laboratory features of all published cases, including ours. Many symptoms and findings are similar to those seen in primary hypothyroidism. However, thyroid-stimulating hormone levels are normal. Free triiodothyronine (T3) levels are in the upper half of normal range or frankly high and free thyroxine (T4) levels are low or in the lower half of normal range. Alterations in free T3 and free T4 may not be remarkable, particularly in adults, possibly contributing to underdiagnosis. In such patients, low reverse T3 levels, normo- or macrocytic anemia or, particularly in children, mildly elevated creatine kinase levels would warrant THRA sequencing. Treatment with L-thyroxine results in improvement of some clinical findings.

Keywords: Constipation, developmental delay, growth failure, central hypothyroidism, autism spectrum disorder, LT4, impaired sensitivity to thyroid hormone
\end{abstract}

\section{Introduction}

The thyroid gland has important roles in energy homeostasis, skeletal growth, cardiac and gastrointestinal function, and maturation of the central nervous system (1). Thyrotropinreleasing hormone (TRH) produced by the hypothalamus stimulates the pituitary gland to release thyroid-stimulating hormone (TSH), which results in synthesis and secretion of thyroid hormones (TH) from the thyroid. The term $\mathrm{TH}$ comprises $\mathrm{T} 4$ (thyroxine, a prohormone and the predominant product of thyroid) and T3 (tri-iodothyronine, the bioactive hormone). A negative-feedback mechanism provides balance between TH levels and TRH-TSH production (2).

TH enter cells via a number of membrane transporters, including tissue specific entities such as monocarboxylate transporter 8 (MCT8) in the central nervous system (3). Intracellular deiodinase enzymes regulate $\mathrm{TH}$ concentrations and convert T4 to T3 and various metabolites (4). T3 binds nuclear receptor proteins and regulates target gene transcription. In the absence of $\mathrm{T} 3$, receptor-protein complexes repress basal gene transcription (5). There are two types of TH receptor (TR): alpha (TR $\alpha)$ and beta (TR $\beta)$. These receptors are highly homologous and encoded by the genes THRA (chromosome 17) and THRB (chromosome 3), respectively. TR $\alpha$ has two isoforms produced with alternative splicing. TR $\alpha 1$ is mainly expressed in the central nervous system, bone, myocardium, skeletal muscle and gastrointestinal tract, while $\mathrm{TR} \alpha 2$ is expressed in various tissues but has no binding site for $\mathrm{T} 3$ and thus its function is enigmatic $(6,7)$. TR $\beta 1$ is predominantly expressed in liver, kidney, thyroid gland, brain, pituitary, and inner ear. TR $\beta 2$ expression is limited to the hypothalamus, pituitary gland, inner ear and retina, and plays the main role in the hypothalamic-pituitary-thyroid (HPT) axis (6-8).

Variants in TR genes cause particular forms of resistance to TH (RTH) (9). The first instance of this disease spectrum was reported by Refetoff et al (10) in 1967. However, demonstration of the underlying genetic defect in THRB took more than two decades (11). Pathogenic variants in THRB result in RTH beta (RTH $\beta$, dominant OMIM \#614450 and recessive OMIM \#274300). The incidence of RTH $\beta$ is reported to be approximately $1 / 40000$ and is characterized
Address for Correspondence: Korcan Demir MD, Dokuz Eylül University Faculty of Medicine, Department of Pediatric Endocrinology, İzmir, Turkey

Phone: + 902324126077 E-mail: korcandemir@gmail.com ORCID: orcid.org/0000-0002-8334-2422

${ }^{\circ}$ Copyright 2021 by Turkish Pediatric Endocrinology and Diabetes Society

The Journal of Clinical Research in Pediatric Endocrinology published by Galenos Publishing House.
Conflict of interest: None declared Received: 15.11 .2019 Accepted: 26.04.2020 
by goiter, tachycardia, hyperactivity, failure to thrive and cognitive impairments with high serum TH levels, but normal or mildly elevated TSH (12-14). The first case of TH resistance in TR $\alpha$ (RTH $\alpha$, OMIM \# 614450) due to a pathogenic, heterozygous variant in THRA, was published in 2012 by Bochukova et al (15). To date, 40 cases (13 adults, 27 children) from 28 different families with 25 different variants in THRA gene have been published (Tables 1,2) (15-32).

The main symptoms and findings of RTH $\alpha$ include varying degrees of constipation, developmental delay, growth failure, and anemia, which are associated with the tissues where $\mathrm{TR} \alpha$ is the main TR and are common to both primary hypothyroidism and RTH $\alpha$. In the former, there is inadequate $\mathrm{TH}$ to induce $\mathrm{TR} \alpha$ while reduced activity of TR $\alpha$ is the mechanism in the latter (33). Furthermore, there are interesting additional features in some of the cases with RTH $\alpha$ including skin tags $(18,19,25)$, epilepsy $(18,23)$, and the individual clinical picture or laboratory findings becoming less remarkable with age $(17,24)$. The disease is thought to be underdiagnosed, given that serum $\mathrm{TH}$ levels are not distinctive as is seen in RTH $\beta$, and TSH is not elevated since TR $\beta$ is intact $(33,34)$.

\section{Genetics}

To date, 25 different variants in THRA have been published (Tables 1,2). Six variants were inherited from an affected parent. Three of the 25 variants were frameshifts, which affected four cases more severely $(16,18,24)$. Three distinct variants resulted in a premature stop codon $(21,28,31)$. However, most of the variants in THRA were missense mutations (15,19-26,29,30,32). All of the RTH $\alpha$ patients were heterozygous for the variant, showing that mutant TR $\alpha$ had a dominant-negative effect on the wild-type receptor, in a similar fashion to RTH $\beta$ (33). It should be noted that some of the variants have not been functionally characterized $(20,21,26-29,31)$. In addition, one of the variants (c.1044G > T) found among subjects with autism spectrum disorder was a synonymous substitution (26).

The reported cases showed that there was a genotypephenotype correlation in patients with RTH $\alpha$. The most severe cases tended to have frameshift variants, but missense variants usually caused a milder phenotype $(18,21,24)$. In addition, patients with the same variants in THRA can present with different clinical phenotypes, suggesting that additional factors, possibly cofactor proteins, affect $\mathrm{TH}$ activity (35).

It was reported that, in the presence of high T3 levels, mutant TR $\alpha$ can exhibit some degree of transcriptional activity, in a similar fashion to the wild-type receptor. This finding suggests that increased circulating T3 levels might have some benefit in ameliorating the dominant-negative activity of mutant $T R \alpha$, although it is not clear whether high levels of $\mathrm{T} 3$ are a result of a compensatory mechanism $(19,23,24)$. With the exception of one case with a mutation in both TR $\alpha 1$ and 2, who presented with severe atypical malformations (22), similar clinical features have been observed due to variants affecting either TR $\alpha 1$ alone or TRa1/2 (33).

\section{Pathophysiology}

The mutant TR $\alpha$ behaves as a dominant-negative repressor of T3 target gene expression in RTH $\alpha$ and also inhibits the function of wild-type TR (15). TR $\alpha$ and TR $\beta$ act via transcriptional repressors, such as nuclear receptor corepressor-1 (NCoR1), in the absence of T3. This effect results in modification of histone deacetylase (HDAC) enzymes into a co-repressor complex, which suppresses basal T3 target gene transcription with remodeling of chromatin (36). When T3 binds to its receptors, a structural change is initiated, which results in disruption of TR and NCoR1. Furthermore, modification of nuclear receptor coactivators initiate the expression of T3 target genes $(37,38)$.

If TR $\alpha$ is mutant, it cannot release NCoR 1 as a response to T3. Consequently, T3 target gene transcription remains suppressed because of the inhibition of wild-type TR through constant HDAC-induced chromatin remodeling. In the light of this molecular information, RTH $\alpha$ demonstrates clinical features with reduced T3 action in related tissues. In addition, a dominant-negative potential of the mutant TR $\alpha$ determines the severity of disease (38).

\section{Clinical Features}

The first experimental study of TR $\alpha$ was reported in 1997, 15 years before the first human cases were reported, showing that a TR $\alpha$ knock-out mouse had postnatal growth arrest with delayed maturation in small intestine and bones (39).

Data regarding physical features of patients with RTH $\alpha$ are generally limited and heterogeneous in the published reports. No descriptive data were given for seven children who were shown to have THRA variants during genetic analyses for autism spectrum disorder $(20,26)$. The clinical features and underlying mechanisms, mainly derived from animal studies, are summarized in Table 3.

\section{Appearance}

Patients with RTH $\alpha$ are usually born after an uneventful pregnancy (33). In severe cases, macroglossia, coarse facial features, and umbilical hernia have been noted in early 


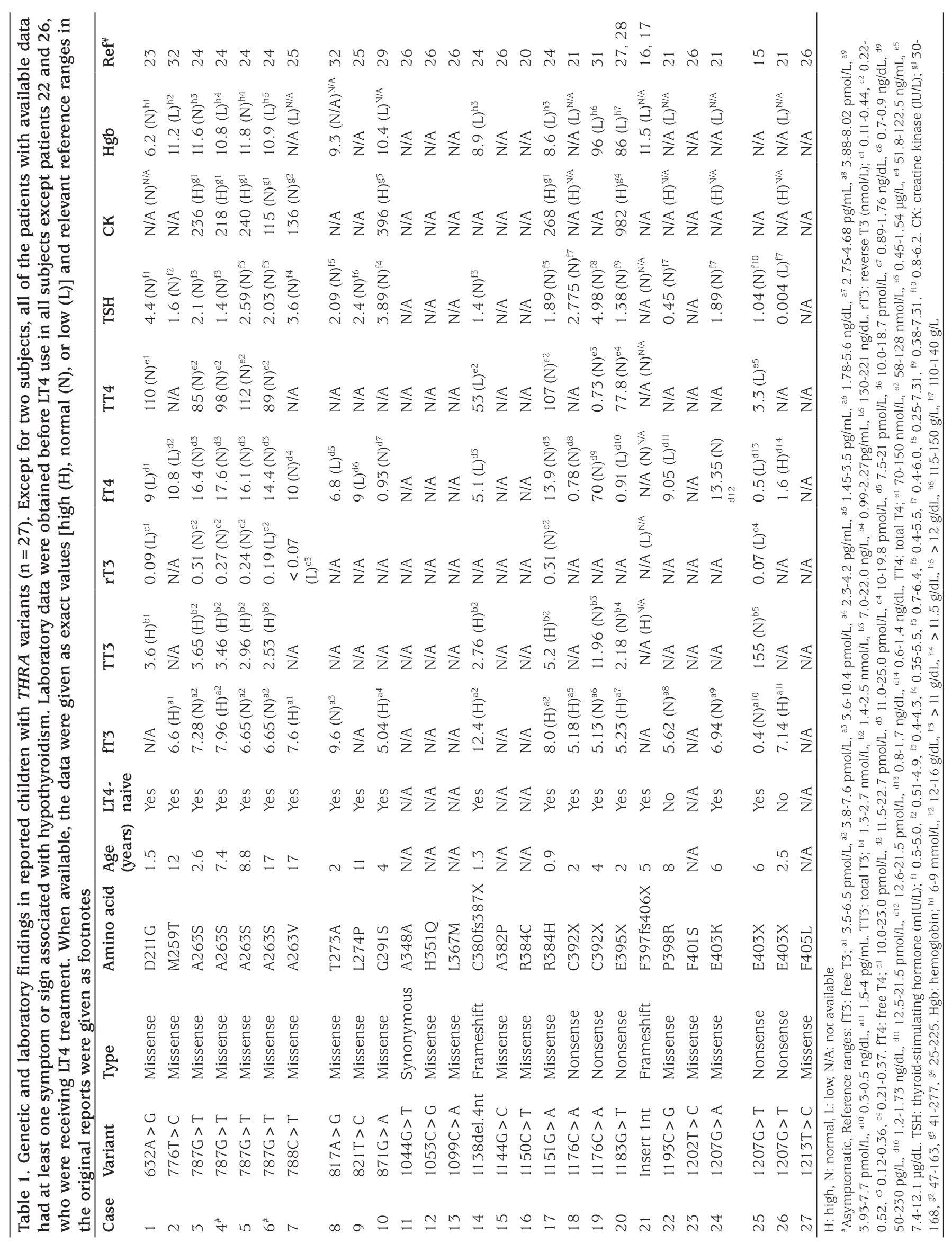




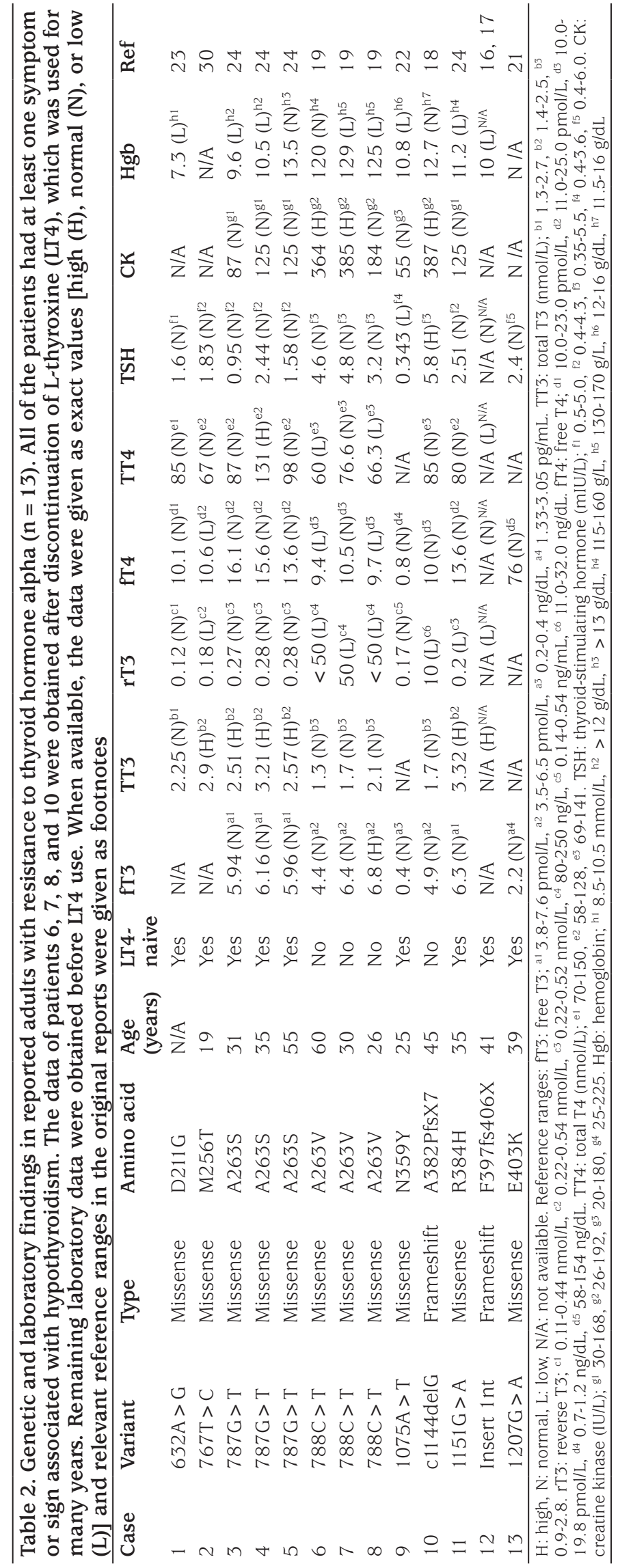

infancy $(18,24,32)$. However, there were also two children with no suggestive symptoms or clinical findings associated with hypothyroidism, who were diagnosed by family screening (24).

Coarse face including macroglossia, flattened large nose, thick lips, deep voice, and hoarse cry are the common features in nearly one third of the patients with RTH $\alpha$ (15,16,18,19,21-25,28-32). In addition, micrognathia and/ or hypertelorism were reported in several cases $(21,22)$.

Rough and dry or thickened skin, reflecting hypothyroidism, has been reported particularly in children in contrast to adult cases $(16,21,28,31)$. In mice with mutant $T R \alpha$, tissue iodothyronine deiodinase (DIO) 3 levels were reduced (40). In addition, topical inhibition of DIO3 enzyme was demonstrated to increase keratinocyte proliferation in animal models $(40,41)$. Therefore, dermal symptoms in TR $\alpha$ patients are thought to be related to a similar mechanism. Skin tags were present in $21 \%$ of cases with RTH $\alpha$; seven among 33 cases with available data $(18,19,24,25)$. Bilateral inguinal hernia and umbilical hernia were reported in two children $(25,29)$.

\section{Skeletal Findings}

Skeletal manifestations such as growth retardation, patent cranial sutures, epiphyseal dysgenesis, and delayed dental eruption have been demonstrated in mice with mutant TR $\alpha 1$ receptor $(42,43)$. In addition, mice with THRA variant presented with decreased endochondral and intramembranous ossification, with retarded closure of skull sutures (44). Delayed ossification in these animal models caused impaired bone remodeling and thus short stature with skeletal deformities. However, bone strength was normal, which may explain why pathologic fractures are not seen in humans with RTH $\alpha$ (43). Further molecular studies demonstrated that mutant TR $\alpha$ caused reduced transcription of target genes including growth hormone receptor, insulin-like growth factor-1 (IGF-1) or its receptor and fibroblast growth factor receptor-1 or -3 . Moreover, decreased signaling in post-receptor pathways in osteoblasts or chondrocytes was reported (45-50).

Short stature is one of the most common clinical findings in children with RTH $\alpha$ (12 among 20 children with available data, $60 \%$ ). Ten of the 12 short children did not receive L-thyroxine (LT4) therapy before diagnosis and the lowest height standard deviation (SD) score was -3.1 (15,16,21,23$25,28,29)$. A previously untreated, three years and 11 months old Chinese female was reported with a height of $85.5 \mathrm{~cm}$ but the SD score was not provided (31). All of the remaining eight children with normal height had missense variants. Six of them (85.7\%) had a height SD score between 
Table 3. Summary of clinical features and underlying mechanism for resistance to thyroid hormone alpha. Pathophysiological mechanisms were observed from animal models, except for hematological findings

\begin{tabular}{|c|c|c|}
\hline Affected system & Pathophysiology & Clinical features \\
\hline Skin & $\begin{array}{l}\text { - Reduced DIO3 levels } \\
\text { - Increased } \\
\text { keratinocyte } \\
\text { proliferation }\end{array}$ & $\begin{array}{l}\text { - Coarse face } \\
\text { - Macroglossia } \\
\text { - Thickened skin } \\
\text { - Skin tags }\end{array}$ \\
\hline Skeletal & $\begin{array}{l}\text { - Delayed ossification } \\
\text { - Impaired bone } \\
\text { remodeling } \\
\text { - Reduced } \\
\text { transcription of target } \\
\text { genes such as growth } \\
\text { hormone receptor, } \\
\text { IGF-1 or its receptor } \\
\text { and fibroblast growth } \\
\text { factor receptor- } 1 \text { or } 3\end{array}$ & $\begin{array}{l}\text { - Short stature } \\
\text { - Wormian bones } \\
\text { - Cranial } \\
\text { hyperostosis } \\
\text { - Macrocephalia } \\
\text { - Skeletal } \\
\text { deformities } \\
\text { - Delayed bone age } \\
\text { - Delayed tooth } \\
\text { eruption }\end{array}$ \\
\hline $\begin{array}{l}\text { Neurological } \\
\text { and cognitive }\end{array}$ & $\begin{array}{l}\text { - Impaired } \\
\text { neuronal migration, } \\
\text { synaptogenesis, } \\
\text { maturation and } \\
\text { myelination } \\
\text { - Deficient } \\
\text { differentiation of } \\
\text { oligodendrocytes or } \\
\text { glial cells } \\
\text { - Abnormal evolution } \\
\text { of GABAergic neurons }\end{array}$ & $\begin{array}{l}\text { - Delayed } \\
\text { milestones } \\
\text { - Impaired cognitive } \\
\text { functions } \\
\text { - Motor } \\
\text { incoordination } \\
\text { - Slow movements } \\
\text { - Dyspraxia } \\
\text { - Speech delay } \\
\text { - Dysarthric speech } \\
\text { - Seizures } \\
\text { - Anxiety } \\
\text { - Autism spectrum } \\
\text { disease }\end{array}$ \\
\hline Gastrointestinal & $\begin{array}{l}\text { - Shortened } \\
\text { villi, increased } \\
\text { differentiation in } \\
\text { crypt cells and } \\
\text { decreased stem cell } \\
\text { proliferation } \\
\text { - Decreased } \\
\text { peristaltism }\end{array}$ & - Constipation \\
\hline Cardiovascular & $\begin{array}{l}\text { - Impaired } \\
\text { cardiac myoblast } \\
\text { differentiation } \\
\text { - Weak cardiac } \\
\text { contractions }\end{array}$ & $\begin{array}{l}\text { - Bradycardia } \\
\text { - Cardiomyopathy } \\
\text { - Pericardial effusion }\end{array}$ \\
\hline Metabolic & $\begin{array}{l}\text { - Impaired facultative } \\
\text { thermogenesis } \\
\text { - Hyperphagia }\end{array}$ & $\begin{array}{l}\text { - Obesity } \\
\text { - Low metabolic rate } \\
\text { - Hyperlipidemia }\end{array}$ \\
\hline Hematological & $\begin{array}{l}\text { - Compromised } \\
\text { fetal and adult } \\
\text { erythropoiesis } \\
\text { - Slowed down } \\
\text { differentiation of } \\
\text { progenitor cells } \\
\text { - Increased serum IL-8 } \\
\text { levels }\end{array}$ & $\begin{array}{l}\text { - Normocytic or } \\
\text { macrocytic anemia }\end{array}$ \\
\hline
\end{tabular}

IGF-1: insulin-like growth factor-1, IL-8: interleukin-8
-1.66 and 0 and none of them had received any treatment. Half of the 12 adult cases with available data had normal height, the tallest being $186 \mathrm{~cm}$. All of them had missense variants and three had received LT4 starting from childhood $(16,18,19,21-24)$.

Wormian bones in skull sutures were present in 10 among 31 cases with available data (32\%) $(15,24,25)$. Various other skeletal deformities, including delayed bone age, genu valgum, coxa valga, short tubular hand bones, late closure of fontanelles, and femoral epiphyseal dysgenesis were also reported (15,19,21,22,24,25,28,29,31). Mesomelic shortening of upper and lower limbs cause increased sitting/ total height ratio $(21,24,25)$. Skull radiography showed cranial hyperostosis in some patients $(18,19,24)$. Espiard et al (22) reported a 27 years-old case with RTH $\alpha$, who had severe deformities resembling cleidocranial dysplasia (clavicular agenesis, humero-radial synostosis, syndactyly of toes, agenesis of the $12^{\text {th }}$ ribs and scoliosis). However, these findings were atypical for RTH $\alpha$ and have not been reported in any other case to date. Bone mineral density was reported to be normal in three adult patients (19).

Normally, tooth eruption is expected to occur before 13 months of age (51). Delayed tooth eruption was detected in eight among 18 children with available data (44\%) $(15,24,25,29)$.

Bochukova et al (15) reported a mild hypermobility and ligamentous laxity in ankles and knees. Although muscle tone was decreased in some cases with RTH $\alpha$, their muscle strength was almost normal (15).

\section{Neuromotor Development}

T3 and its receptors play a major role in neuronal migration, synaptogenesis, maturation, myelination and differentiation of oligodendrocytes or glial cells (52). That is why TR $\alpha$ knockout animals showed a severe delay in postnatal development and locomotor dysfunction (53). TR $\alpha$ disruption had significant effects on cerebellar formation and hippocampal functions and TR $\alpha$ mutant mouse models had reduced brain mass (54-56). Wilcoxon et al (57) demonstrated behavioral inhibition and decreased learning and memory function in mice lacking all isoforms of TR $\alpha$.

In infants with RTH $\alpha$, delayed milestones for motor and speech abilities are the most common symptoms, noted in 34 among 40 cases (85\%) (15,16,18-21,23-26,28-32). Reduced IQ, notable impairments in cognitive functions, slow motion movements, evident motor discoordination including dyspraxia, ataxia, and broad or unstable gait are some of the clinical findings on neurological examination 
$(15,18,19,24,28,32)$. Remarkably, two cases with the A263V variant were able to attend university without LT4 treatment (Demir-unpublished observation of Patient 3.III.1 in reference 24,25). The first patient had no symptoms and was detected during family screening (24). The second case had mild delay in motor and mental development during childhood and received little teaching support (25). Axial hypotonia and slow motor development can also be seen (23). Clumsiness due to motor discoordination and difficulty with fine motor abilities has been reported in some patients, who were incapable of writing or drawing $(15,18,28)$. Speech delay and dysarthric or slow speech are significant disabilities and are seen in the majority of cases $(15,16,18,19,21,23,24,28)$. Macrocephalia is also a common clinical finding ( 23 among 33 cases with available data, $70 \%)(15,16,18-25,29-31)$.

Furthermore, Demir et al (24) reported a 35-year-old adult case, whose developmental delay during childhood was more remarkable compared to her affected son. As an adult, she presented with an attenuated clinical picture including mild intellectual deficit, no cardiac problems, and normal thyroid function tests, despite not being treated. Similar observations were also made in a mouse model with a heterozygous TR $\alpha 1$ variant at the same position $(53,58)$. These mice showed severe but transient impairment of postnatal development and growth. The mechanisms underlying the amelioration of deficits caused by these TR $\alpha 1$ variants with age are unknown.

Seizures after stimulation with light or audio and abnormal evolution of GABAergic neurons in TR $\alpha 1$ mutant mice correlated with epilepsy in human cases $(42,59,60)$. To date, three cases with RTH $\alpha$ were reported to be suffering from epileptic seizures in childhood $(18,23,32)$.

A notable anxiety in unfamiliar environments and reduced cognitive functions were observed in TR $\alpha 1$ mutant animal models (59). Another study demonstrated that TR $\alpha 1$ mutant mice developed depressive and anxiety behaviors (61). Kalikiri et al (26) investigated 30 children diagnosed as autism spectrum disorder and found THRA variants in six of them. Unfortunately, no additional clinical data regarding these children were provided. Coexistence of autism spectrum disorder and RTH $\alpha$ was reported in two more patients, suggesting that RTH $\alpha$ should be excluded in patients with autism spectrum disorder $(20,31)$.

\section{Constipation}

$\mathrm{TR} \alpha$ is the dominant $\mathrm{TR}$ in the intestinal tract $(6,7)$. In a study with TR $\alpha 1$ mutant mice models, shortened villi, increased differentiation in crypt cells and decreased stem cell proliferation were observed (62). Independent of age, constipation is one of the most common clinical symptoms in human cases, being reported in 26 among 31 cases with available data (84\%) (15,16,18,19,21,23-25,28,29,31,32). The atypical patient reported by Espiard et al (22), was the only patient to develop chronic diarrhea, at the age of 12 . Abdominal radiographs showed dilated bowels. Decreased peristalsis was also observed by colonic manometry in several cases with RTH $\alpha(15,18)$.

\section{Cardiovascular System}

TR $\alpha 1$ is expressed in myocardium and it was suggested to be responsible for cardiac myoblast differentiation in experimental studies (63). Mutant TR 1 mice models showed symptoms in the cardiovascular system associated with hypothyroidism, such as bradycardia or weak cardiac contractions (64). Makino et al (65) found that the predominant TR in mouse coronary smooth muscle cells was TR $\alpha$, and suggested that coronary vascular tone was regulated by $\mathrm{TR} \alpha$. However, cardiac pathologies or symptoms do not seem to be common in humans with RTH $\alpha$. Although most of the patients had normal heart rate or blood pressure, some cases were reported to have bradycardia $(15,18,19)$. At the time of writing, three cases with cardiomyopathy and one case with pericardial effusion have been reported $(21,24)$.

\section{Metabolic Problems and Fertility}

$\mathrm{TR} \alpha$ null or mutant mice had lower core body temperature due to impaired facultative thermogenesis (66). Although most of the animal models with mutant TR $\alpha$ were thin, several studies described obesity (58). In the same study, it was also reported that the TR $\alpha 1 \mathrm{R} 384 \mathrm{C}$ mutant mice were hyperphagic but resistant to obesity (58). It was suggested that hypermetabolism, mediated centrally through apoTR $\alpha 1$ resulted in reduced adipose tissue and lower body weight (67). However, eight among 33 humans diagnosed as RTH $\alpha$ with available data (24\%) were obese and six of them were adults $(15,18,23,24)$. Low resting energy expenditure (metabolic rate) was also reported in some patients with RTH $\alpha(15,18,19,22)$. In addition, total cholesterol and lowdensity lipoprotein (LDL) levels were high in several patients $(16,18,19)$.

As RTH $\alpha$ can be seen in children of affected adults, it suggests that fertility might be unaffected in either gender. Regular pregnancies after spontaneous conception were reported, in even moderately affected and untreated female RTH $\alpha$ cases (24). Only one patient had late-onset of puberty and menarche at 16 years-old, with normal gonadotropin and estrogen levels (18). 


\section{Laboratory}

Unfortunately, relevant measurements were inconsistently reported in the published cases and so data is incomplete for all the case reports. In addition, while the majority of available data in the literature were presented as exact values with their reference ranges, some reports included only categorized data (Tables 1,2).

\section{Thyroid Function Tests}

Thyroid function tests of individuals suspected of having RTH $\alpha$ should be cautiously interpreted since the literature data were derived from cases with varying severity of RTH $\alpha$ and from different age groups. Abnormal TH levels are more likely to be found in severe cases and in children. Since the $\mathrm{TH}$ and TSH levels seem to differ if there has been previous LT4 use, we chose to evaluate the data from the cases who had not received LT4 previously (LT4-naive) separately from the patients who were analyzed after discontinuation of LT4 treatment.

\section{Individuals Who had not Receive Any Thyroid Hormone}

A normal neonatal congenital hypothyroidism screening result [total T4 $62 \mathrm{nmol} / \mathrm{L}(-1.3 \mathrm{SD})$, TSH $1 \mathrm{mIU} / \mathrm{L}$ ] was reported in a case with RTH $\alpha$, who also had an uneventful neonatal period (23).
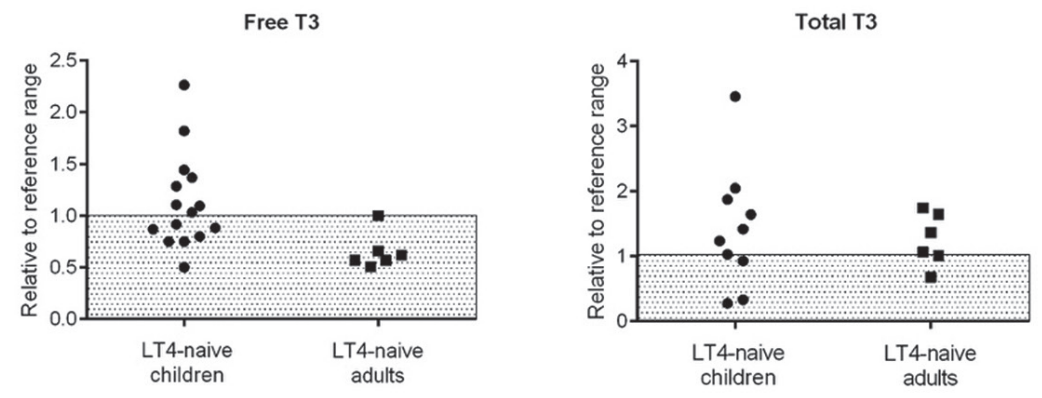

Total T4
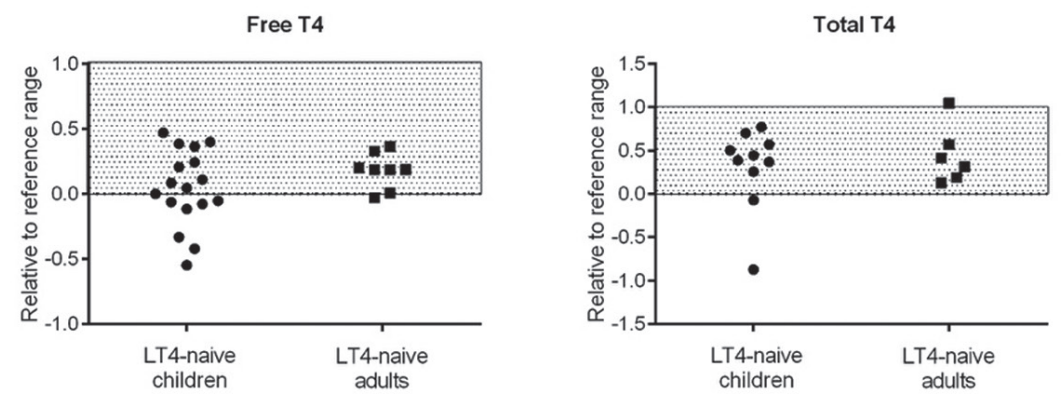

TSH levels were all normal in affected children. Among the adult patients, an atypical case with severe malformations was the only one with abnormal TSH $(0.343 \mathrm{mIU} / \mathrm{L}$, normal range 0.4-3.6) (Figure 1) (22).

Differences of TH levels among treatment-naive children and adults are also shown in Figure 1. All of the free T3 (fT3) and the majority of total T3 levels were in the upper half of normal range or frankly elevated. Elevated fT3 levels were found only in treatment-naive children but not in such adult cases. All of the free T4 (fT4) and the majority of total T4 levels were below the reference range or in the lower half of the normal range. Low fT 4 concentrations were more frequently present among children. In adult patients, fT4 levels were all normal, except for one case (30).

Both fT4 and TSH were normal in 61\% (11 among 18) of children and $78 \%$ (7 among 9) of adults. Normal fT3, fT4 and TSH were noted in $33 \%$ (5 among 15 ) and $83 \%$ (5 among 6) of children and adults, respectively (Figure 2). In such cases, a high T3/T4 ratio or low or low-normal reverse T3 (rT3) level, resulting in an increased T3/rT3 ratio can be suggestive of RTH $\alpha$ (33). These abnormalities in RTH $\alpha$ patients may be the result of changes of DIO1 and DIO3 levels in tissues, as the expression of both are regulated by TR $\alpha$. In a study, TR 1 mutant mice had raised hepatic DIO1 levels, which converts T4 to T3 (42). Therefore, this

Figure 1. Thyroid function test results in previously untreated children and adults [derived from all available data in Table 1 (Cases 1-10, 14, 17-20, 24, and 25) and Table 2 (Cases 1-5, 9, 11, and 13)]. All of the data (x) was expressed relative to the relevant reference range with the following formula: ( $\mathrm{x}$ - lower limit of normal range) / (upper limit of normal range - lower limit of normal range). Grey shaded areas indicated the normal range 
finding was related to high T3 levels and an increased T3/T4 ratio in RTH $\alpha$. In addition, decreased DIO3 levels in tissues may result in low rT3 levels, causing reduced inner-ring deiodination of T4 to rT3 (40).

\section{Individuals Who Discontinued Treatment}

After cessation of LT4 treatment, mildly elevated TSH may be seen, as was reported in one adult and one child with RTH $\alpha(17,18)$. The child, in whom TSH rose at the age of 11 after discontinuation of LT4, had normal pretreatment TSH levels at 5 and 6 years of age (17). In contrast, TSH remained in the normal range in three adult patients and an adolescent case $(19,25)$ after LT4 cessation. Off thyroxine treatment, patients had marginally low or low-normal fT4. A wide range of free or total T3 data (varying from the lower half of the normal range to elevated levels) was reported. Nevertheless, rT3 levels were all low (17-19,25).

\section{Individuals Receiving Thyroid Hormone}

Under LT4 treatment, fT3 and fT4 levels increased in patients with RTH $\alpha$, while TSH was suppressed, a similar pattern to that found during the treatment of central hypothyroidism $(15,17-19,23,24,29)$. One patient with atypical phenotype was treated with liothyronine, which caused a rise in fT3 level, suppressed TSH level, and markedly reduced fT4 concentration (22).

\section{Anemia}

The relationship between anemia and hypothyroidism is well-known (68). Animal models lacking TR $\alpha$ demonstrated compromised erythropoiesis $(69,70)$. In a study by van Gucht et al (71) of progenitor cells derived from RTH $\alpha$ patients, it was shown that these cells differentiated more slowly than controls. In humans, 23 among 30 cases with available data $(77 \%)$ had anemia, and it has been one of the most common findings in humans with RTH $\alpha(16,18,19,21$ $25,28,29,31,32)$. The rate of anemia was similar between treatment-naive children ( $80 \%)$ and adults (86\%) (Figure 2). In the reports where exact values were included, hemoglobin levels ranged between 8.6-10.9 g/dL and 9.6-12.9 g/dL in children and adults, respectively. In the majority, anemia was normocytic and normochromic; macrocytic anemia was described in three cases $(13 \%)(15,18,22)$.

An increase in serum levels of interleukin-8 (IL-8), a proinflammatory cytokine, was shown in RTH $\alpha$ patients. However, neutrophil or macrophage functions, which are partly mediated by IL-8, were found to be normal in those cases (72).

\section{Other Biochemical Findings}

Both thyroglobulin and urinary iodine levels are expected to be in the normal range (34). Similar to primary hypothyroidism, high total cholesterol and LDL levels, and low or low-normal levels of IGF-1 can be found in RTH $\alpha$ $(33,34)$.

In primary hypothyroidism, creatinine kinase (CK) can also be elevated (73). Human data demonstrate that $\mathrm{CK}$ might be a promising biomarker for diagnosis of RTH $\alpha$, particularly in children. Eight among 11 treatment-naive children $(73 \%)$ with available data had elevated CK levels (range; 218-981 U/L; 1.3-4.36 times upper limit of normal), while all of the treatment-naive adults with available data $(\mathrm{n}=5)$ had normal CK levels (Figures 2 and 3) $(15,16,22$ $25,28,29,31)$. In contrast, elevated CK levels were noted in three of four adult patients (364-387 U/L; 1.90-2.02 times upper limit of normal) and in the two children (196-213 U/L; 1.03-1.31 times upper limit of normal) who were assessed after discontinuation of LT4 (17-19,25).

Recently, Boumaza et al (74) reported that biofluids (urine and plasma samples) of TR $\alpha$-mutant mice showed distinct metabolomic profiles from controls, including increased urinary levels of hippurate and decreased urinary levels of isovalerylglycine, dimethylamine, trimethylamine, and choline. They suggested that easily accessible nuclear magnetic resonance-based metabolic fingerprints of biofluids could be used to diagnose RTH $\alpha$ in humans (74).

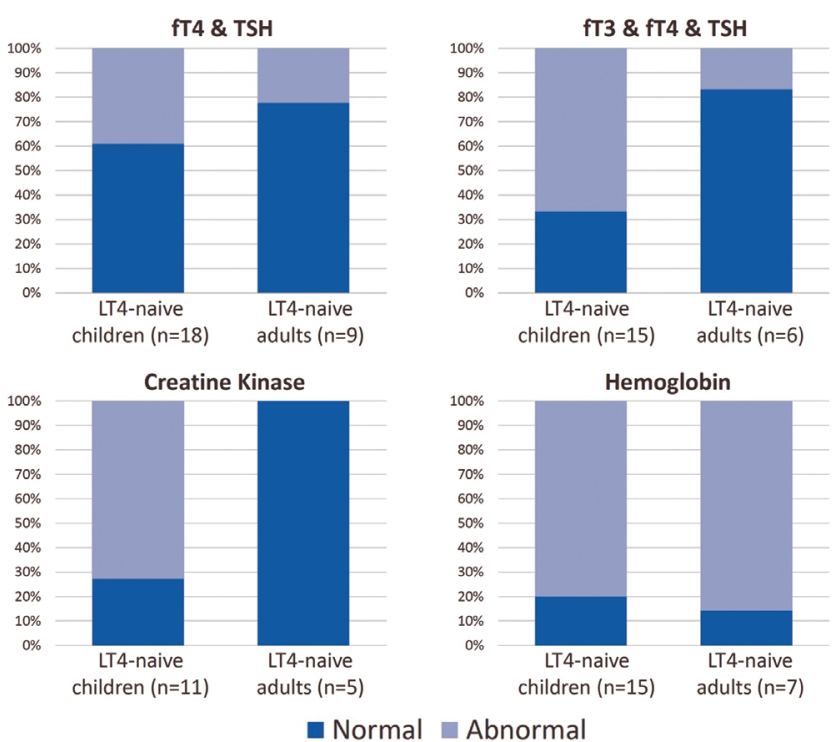

Figure 2. Classification of thyroid hormone profiles and peripheral indicators of hypothyroidism belonging to previously untreated children and adults [derived from all available data in Table 1 (Cases 1-10, 14, 17-21, 24, and 25) and Table 2 (Cases 1-5, 9, and 11-13)]

LT4: L-thyroxine, fT3: free T3, fT4: free T4, TSH: thyroid-stimulating hormone 


\section{Differential Diagnosis}

RTH $\alpha$ should come to mind when various clinical features indicate hypothyroidism but TSH is normal and free T4 is low or in lower half of normal range in patients who have not received LT4 treatment (Figure 4). Parental medical history should be investigated thoroughly for similar clues due to autosomal dominant inheritance. More common conditions including non-thyroidal illness, recovery from thyrotoxicosis, or technical assay problems, may result in similar biochemical features (75). However, they are not associated with clinical features of RTH $\alpha$.

Central hypothyroidism should be ruled out when free T4 is low and TSH is low, normal, or slightly elevated. The presence of hypothalamic-pituitary disease, hypo- or hypersecretion of other pituitary hormones or genetic findings would indicate an etiology of central hypothyroidism (75). On the other hand, if T3 levels are elevated or close to the upper limit, the probability of central hypothyroidism is low.

Laboratory findings including elevated/normal T3, reduced rT3, normal or low T4, and normal/elevated TSH are also found in MCT8 deficiency (Allan Herndon Dudley syndrome). However, clinical and laboratory signs of peripheral thyrotoxicosis are present in this disease in addition to cerebral hypothyroidism (76-79). Furthermore,

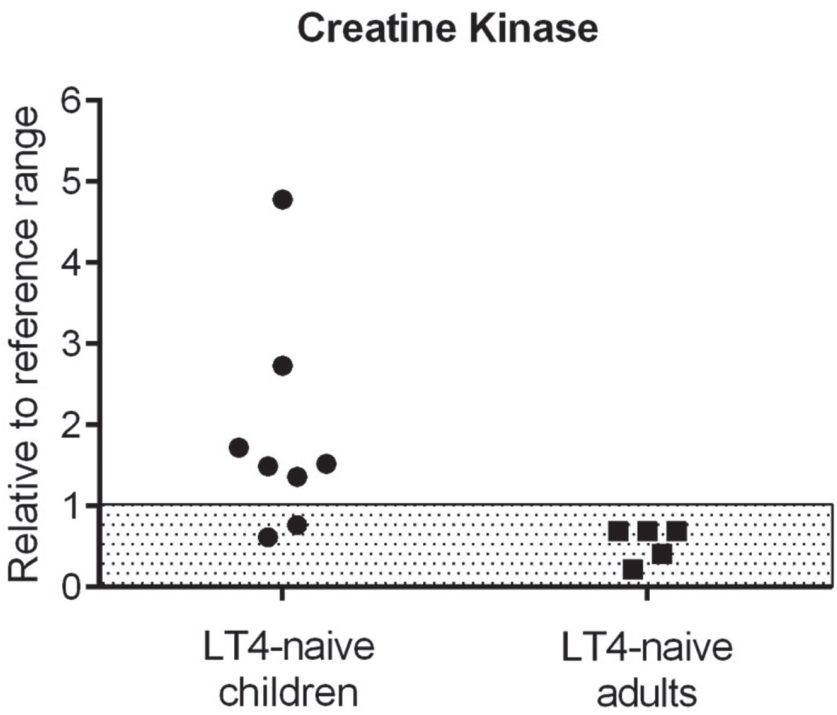

Figure 3. Numerical values of creatine kinase levels obtained from previously untreated children and adults with resistance to thyroid hormone alpha [derived from all available data in Table 1 (Cases 3-7, 10, 17, and 20) and Table 2 (Cases $3-5,9$, and 11)]. All of the data (x) was expressed relative to the relevant reference range with the following formula: ( $x$ - lower limit of normal range) / (upper limit of normal range lower limit of normal range). Grey shaded area indicated the normal range

LT4: L-thyroxine
MCT8 deficiency is inherited in an X-linked manner (80). Thus, the mothers of affected patients, all of whom would be expected to be male, are asymptomatic carriers. However, an affected parent can be found in case of RTH $\alpha(16,21,23$ $25,77,78)$.

Additional clues for RTH $\alpha$ in LT4-naive children and adults are free or total T3 in the upper half of the normal range or above the upper limit, along with at least one of normocytic/ macrocytic anemia or mildly elevated CK or low rT3. Among the subjects with available data, the algorithm in Figure 4 is valid for 15 of 16 children ( $94 \%$ ) and for six of eight adults (75\%) (15-17,21,22-25,27-32). When the data of four additional adult cases, whose assessments were available after discontinuation of LT4, are also included, the algorithm should be modified regarding T3 and TSH data,

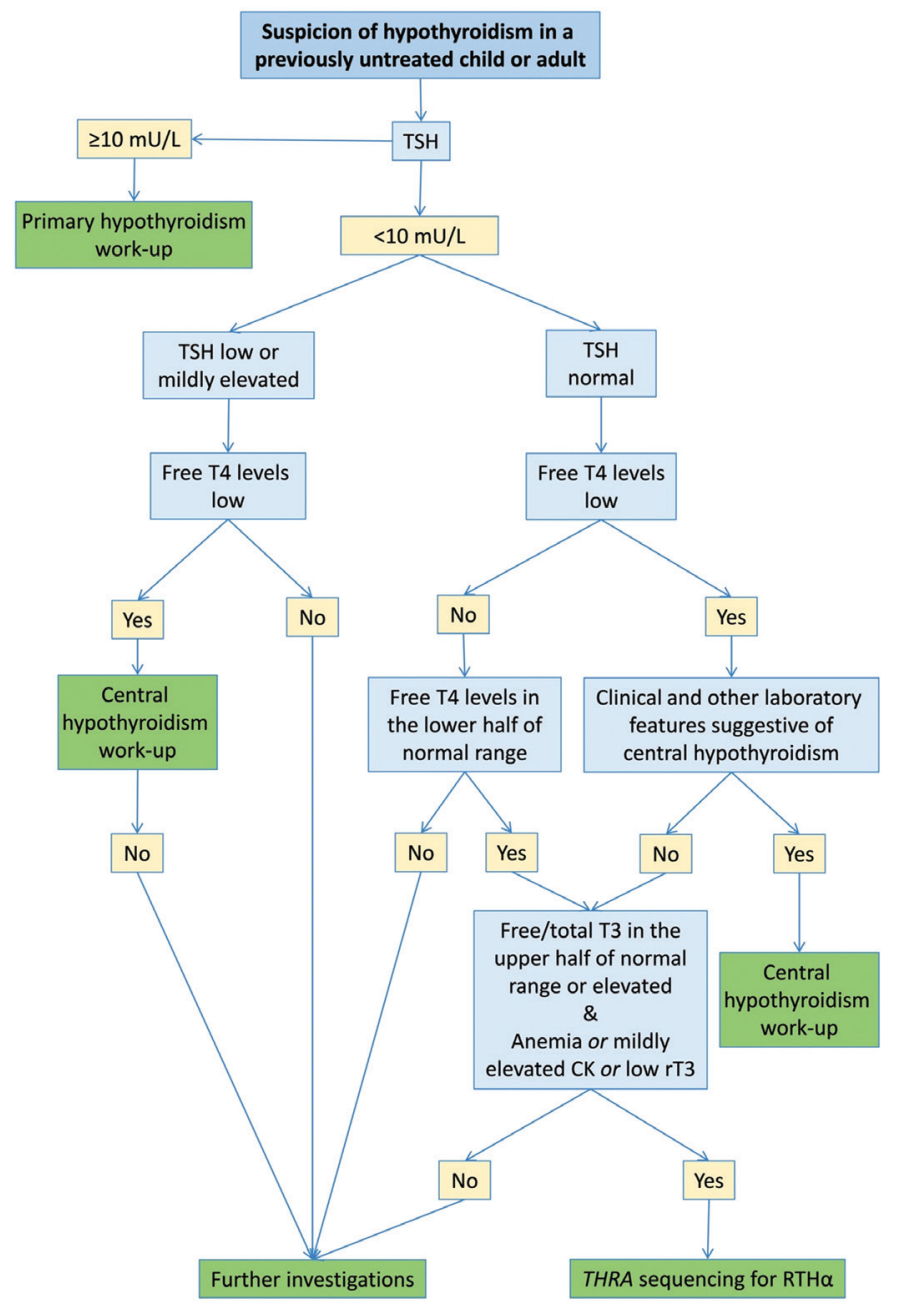

Figure 4. Algorithm for the differential diagnosis of hypothyroidism in previously untreated children and adults with particular emphasis on resistance to thyroid hormone alpha

TSH: thyroid-stimulating hormone, RTHa: resistance to thyroid hormone alpha, CK: creatine kinase, rT3: reverse T3 
given that fT3 levels may also be in the lower half of the normal range and TSH levels can be mildly elevated. In these subjects, after exclusion of central hypothyroidism, presence of either normocytic or macrocytic anemia or mildly elevated CK values or low rT3 levels would be an additional clue leading to THRA sequencing. This approach is valid for 10 of 12 adult patients with available data ( $83 \%$ ) (16-19,22-24,30). Both approaches require confirmation of these specificities in future studies.

\section{Treatment and Outcomes}

There is only limited data about the treatment of RTH $\alpha$ and thus long-term follow-up data is required. LT4 treatment has been the first choice to date, in order to overcome the resistance in TR $\alpha$ with higher dosage. T4 and rT3 levels come into the normal range with this treatment and T3 level remains high. Since the feedback mechanism of the HPT axis is intact, LT4 treatment causes TSH suppression in RTH $\alpha$ patients (15,17-19,23,24,29).

In animal models with mutant $\mathrm{TR} \alpha$, increasing serum $\mathrm{TH}$ levels alleviated locomotor and behavioral irregularities (59). Therefore, LT4 supplementation to raise circulating TH levels was suggested to be beneficial in RTH $\alpha$. Bassett et al (43) reported that prolonged T4 treatment advanced bone rigidity and strength in TR $\alpha$ mutant mice. However, it did not exert any effect on skeletal development, linear growth or mineralization of bones (43). Vennström et al (58) suggested that high doses of $\mathrm{T} 3$, given in the appropriate developmental time period, should improve the abnormalities depending on the specific mutation present in TR $\alpha$. They also showed that metabolic symptoms of mice with mutant TR $\alpha$, were well treated by T3. Regarding this, Espiard et al (22) reported that their case with an atypical phenotype received liothyronine treatment and a notable cardiac and metabolic response was observed. Nevertheless, other parameters did not change significantly, suggesting that the variant in this case only exhibited limited resistance to T3.

Van Mullem et al (17) reported the results of two RTH $\alpha$ patients (a daughter and her father, with the same variant), who were treated with LT4 for over five years. They showed that some clinical features, such as constipation or nerve conductance, were improved. However, fine motor abilities or cognitive functions did not benefit from treatment (17). On the other hand, most of the LT4 treated patients had better motor coordination, alertness, school performance, concentration or motivation (19,25,29,31). However, limited benefit on linear growth has been reported $(15,17,23)$. Hypotonia was ameliorated and accelerated neuromotor development was observed in children $(23,31,32)$. Thus, if the treatment was started at an early age, the benefits for development and growth would be more distinguishable. As described in the report by van Mullem et al. (17), constipation improved with LT4 treatment in most of the other RTH $\alpha$ cases $(15,19,25,29)$.

With the peripheral effects of LT4 treatment, increases in sex hormone binding globulin (SHBG) or IGF-1 levels can be seen, as previously reported in RTH $\alpha$ patients. In addition to this, CK or cholesterol levels were reduced in these cases, reflecting the improved tissue response to TH (15,17-19,2325). It has also been shown that when LT4 treatment was interrupted, all these indicators turned back to pretreatment levels (17). Korkmaz et al (29) reported a decrease in SHBG levels and found IGF-1 levels unaltered after LT4 treatment in a patient with RTH $\alpha$, although the TSH level was suppressed and CK levels were decreased. Moran et al (18) reported a progressive rise in bone turnover markers after LT4 treatment in a case with RTH $\alpha$. Growth hormone was added to LT4 therapy, due to low-normal IGF-1 levels in an affected child, but sufficient improvement in linear growth was not observed (17).

Anemia seems to be unresponsive to LT4 treatment, as described in most of the RTH $\alpha$ cases $(18,19,25,29)$. Although van Gucht et al (71) showed that human erythroid progenitors responded to T3 exposure in an experimental study, they hypothesized that mutant $\mathrm{TR} \alpha$ may play a role in the earlier stages of erythropoiesis, which they could not examine in their research. In addition, LT4 treatment had a limited effect on cardiac function in several cases with RTH $\alpha(18,19)$. Increase in heart rate was observed in one patient after LT4 treatment (22).

Patients who had frameshift variants in THRA, including the carboxy-terminal part of TR $\alpha 1$, had varying responses to LT4 treatment. Like their severity of clinical presentation, this situation was also associated with the specific location of the variant or the degree to which this molecular region was affected $(17,18,24)$. In patients with frameshift variants skeletal abnormalities did not respond to LT4 treatment $(17,18,24)$.

Since LT4 administration to RTH $\alpha$ patients will excessively stimulate TR $\beta$ in TR $\beta$-dominant tissues, development of TR $\alpha 1$ selective thyromimetics would be ideal $(33,81)$. Alternative investigations targeted HDAC activity or interaction with the co-repressor complex to inhibit the dominant-negative effect of wild-type analogue of mutant TR $\alpha 1$. It was shown in a murine study that a mutation in NCoR can disrupt its co-action with TR $\alpha 1$ and reverses the effects of mutant TR $\alpha$ (82). An HDAC inhibitor, suberoylanilide hydroxamic acid (SAHA), was used to relieve the repression in target genes and phenotypic features improved in TR 1 mutant 
mice $(81,83,84)$. However, Freudenthal et al (38) showed that SAHA was unlikely to treat skeletal abnormalities and had no effect on bone structure or strength in TR $\alpha$ mutant mouse models. These authors suggested that alternative corepressors, in addition to NCoR, may interact with $\mathrm{TR} \alpha$ in skeletal cells $(36,38)$.

\section{Conclusion}

The diagnosis of RTH $\alpha$ is not straightforward since TH levels might not be helpful and the entity is not widely known. As published data is limited concerning RTH $\alpha$, absence of phenotypic features or laboratory findings would not exclude RTH $\alpha$. Currently, only fT 4 and TSH levels are recommended for evaluation of growth failure in children (85). However, these tests can be normal in a subject with RTH $\alpha$ and astute clinicians should do further investigations in such a case when the clinical picture is similar to hypothyroidism. In addition, RTH $\alpha$ should be kept in mind in patients diagnosed with apparent central hypothyroidism, particularly when the exact etiology cannot be determined.

\section{Ethics}

Peer-review: Externally peer-reviewed.

\section{Authorship Contributions}

Surgical and Medical Practices: İbrahim Mert Erbaș, Korcan Demir, Concept: İbrahim Mert Erbaş, Korcan Demir, Design: İbrahim Mert Erbaş, Korcan Demir, Data Collection or Processing: İbrahim Mert Erbaş, Korcan Demir, Analysis or Interpretation: Ibrahim Mert Erbaş, Korcan Demir, Literature Search: İbrahim Mert Erbaş, Korcan Demir, Writing: İbrahim Mert Erbaş, Korcan Demir.

Financial Disclosure: The authors declared that this study received no financial support.

\section{References}

1. Visser TJ. Regulation of thyroid function, synthesis and function of thyroid hormones. In: Vitti P, Hegedus L (Eds). Thyroid Diseases Endocrinology. Springer, Cham 2018;1-30.

2. Fekete C, Lechan RM. Central regulation of hypothalamic-pituitarythyroid axis under physiological and pathophysiological conditions. Endocr Rev 2014;35:159-194. Epub 2013 Dec 13

3. Visser WE, Friesema EC, Visser TJ. Minireview: thyroid hormone transporters: the knowns and the unknowns. Mol Endocrinol 2011;25:114. Epub 2010 Jul 21

4. St Germain DL, Galton VA, Hernandez A. Minireview: defining the roles of the iodothyronine deiodinases: current concepts and challenges. Endocrinology 2009;150:1097-1107. Epub 2009 Jan 29

5. Horlein AJ, Heinzel T, Rosenfeld MG. Gene regulation by thyroid hormone receptors. Curr Opin Endocrinol Diabetes 1996;3:412-416.
6. Lazar MA. Thyroid hormone receptors: multiple forms, multiple possibilities. Endocr Rev 1993;14:184-193.

7. Cheng SY, Leonard JL, Davis PJ. Molecular aspects of thyroid hormone actions. Endocr Rev 2010;31:139-170. Epub 2010 Jan 5

8. Ng L, Cordas E, Wu X, Vella KR, Hollenberg AN, Forrest D. Age-Related Hearing Loss and Degeneration of Cochlear Hair Cells in Mice Lacking Thyroid Hormone Receptor $\beta 1$. Endocrinology 2015;156:3853-3865. Epub 2015 Aug 4

9. Refetoff S, Bassett JH, Beck-Peccoz P, Bernal J, Brent G, Chatterjee K, De Groot LJ, Dumitrescu AM, Jameson JL, Kopp PA, Murata Y, Persani L, Samarut J, Weiss RE, Williams GR, Yen PM. Classification and proposed nomenclature for inherited defects of thyroid hormone action, cell transport, and metabolism. Thyroid 2014;24:407-409. Epub 2014 Mar 4

10. Refetoff S, DeWind LT, DeGroot LJ. Familial syndrome combining deafmutism, stippled epiphyses, goiter, and abnormally high PBI: possible target organ refractoriness to thyroid hormone. J Clin Endocrinol Metab 1967;27:279-294

11. Sakurai A, Takeda K, Ain K, Ceccarelli P, Nakai A, Seino S, Bell GI, Refetoff S, DeGroot LJ. Generalized resistance to thyroid hormone associated with a mutation in the ligand-binding domain of the human thyroid hormone receptor $\beta$. Proc Natl Acad Sci U S A 1989;86:89778981.

12. Lafranchi SH, Snyder DB, Sesser DE, Skeels MR, Singh N, Brent GA, Nelson JC. Follow-up of newborns with elevated screening T4 concentrations. J Pediatr 2003;143:296-301.

13. Jackowski T, Petriczko E, Horodnicka-Józwa A, Walczak M. Thyroid hormone resistance syndrome - own experiences. Pediatr Endocrinol Diabetes Metab 2017;23:209-214.

14. Pappa T, Refetoff S. Human Genetics of Thyroid Hormone Receptor Beta: Resistance to Thyroid Hormone Beta (RTH $\beta$ ). Methods Mol Biol 2018;1801:225-240

15. Bochukova E, Schoenmakers N, Agostini M, Schoenmakers E, Rajanayagam O, Keogh JM, Henning E, Reinemund J, Gevers E, Sarri M, Downes K, Offiah A, Albanese A, Halsall D, Schwabe JW, Bain M, Lindley K, Muntoni F, Vargha-Khadem F, Dattani M, Farooqi IS, Gurnell M, Chatterjee K. A mutation in the thyroid hormone receptor alpha gene. N Engl J Med 2012;366:243-249. Epub 2011 Dec 14

16. van Mullem A, van Heerebeek R, Chrysis D, Visser E, Medici M, Andrikoula M, Tsatsoulis A, Peeters R, Visser TJ. Clinical phenotype and mutant TR $\alpha 1$. N Eng1 J Med 2012;366:1451-1453.

17. van Mullem AA, Chrysis D, Eythimiadou A, Chroni E, Tsatsoulis A, de Rijke YB, Visser WE, Visser TJ, Peeters RP. Clinical phenotype of a new type of thyroid hormone resistance caused by a mutation of the TR $\alpha 1$ receptor: consequences of LT4 treatment. J Clin Endocrinol Metab 2013;98:3029-3038. Epub 2013 Apr 30

18. Moran C, Schoenmakers N, Agostini M, Schoenmakers E, Offiah A, Kydd A, Kahaly G, Mohr-Kahaly S, Rajanayagam O, Lyons G, Wareham N, Halsall D, Dattani M, Hughes S, Gurnell M, Park SM, Chatterjee K. An adult female with resistance to thyroid hormone mediated by defective thyroid hormone receptor $\alpha$. J Clin Endocrinol Metab 2013;98:42544261. Epub 2013 Aug 12

19. Moran C, Agostini M, Visser WE, Schoenmakers E, Schoenmakers N, Offiah AC, Poole K, Rajanayagam O, Lyons G, Halsall D, Gurnell M, Chrysis D, Efthymiadou A, Buchanan C, Aylwin S, Chatterjee KK. Resistance to thyroid hormone caused by a mutation in thyroid hormone receptor (TR) $\alpha 1$ and TR 2 : clinical, biochemical, and genetic analyses of three related patients. Lancet Diabetes Endocrinol 2014;2:619-626. Epub 2014 Jun 23

20. Yuen RK, Thiruvahindrapuram B, Merico D, Walker S, Tammimies K, Hoang N, Chrysler C, Nalpathamkalam T, Pellecchia G, Liu Y, Gazzellone 
MJ, D'Abate L, Deneault E, Howe JL, Liu RS, Thompson A, Zarrei M, Uddin M, Marshall CR, Ring RH, Zwaigenbaum L, Ray PN, Weksberg R, Carter MT, Fernandez BA, Roberts W, Szatmari P, Scherer SW. Wholegenome sequencing of quartet families with autism spectrum disorder. Nat Med 2015;21:185-191. Epub 2015 Jan 26

21. Tylki-Szymańska A, Acuna-Hidalgo R, Krajewska-Walasek M, LeckaAmbroziak A, Steehouwer M, Gilissen C, Brunner HG, Jurecka A, Różdżyńska-Świątkowska A, Hoischen A, Chrzanowska KH. Thyroid hormone resistance syndrome due to mutations in the thyroid hormone receptor $\alpha$ gene (THRA). J Med Genet 2015;52:312-316. Epub 2015 Feb 10

22. Espiard S, Savagner F, Flamant F, Vlaeminck-Guillem V, Guyot R, Munier M, d'Herbomez M, Bourguet W, Pinto G, Rose C, Rodien P, Wémeau JL. A novel mutation in THRA gene associated with an atypical phenotype of resistance to thyroid hormone. J Clin Endocrinol Metab 2015;100:2841-2848. Epub 2015 Jun 2

23. van Gucht AL, Meima ME, Zwaveling-Soonawala N, Visser WE, Fliers E, Wennink JM, Henny C, Visser TJ, Peeters RP, van Trotsenburg AS. Resistance to thyroid hormone alpha in an 18-month-old girl: clinical, therapeutic, and molecular characteristics. Thyroid 2016;26:338-346. Epub 2016 Feb 16

24. Demir K, van Gucht AL, Büyükinan M, Çatlı G, Ayhan Y, Baş VN, Dündar B, Özkan B, Meima ME, Visser WE, Peeters RP, Visser TJ. Diverse genotypes and phenotypes of three novel thyroid hormone receptor- $\alpha$ mutations. J Clin Endocrinol Metab 2016;101:2945-2954. Epub 2016 May 4

25. Moran C, Agostini M, McGowan A, Schoenmakers E, Fairall L, Lyons G, Rajanayagam O, Watson L, Offiah A, Barton J, Price S, Schwabe J, Chatterjee K. Contrasting phenotypes in resistance to thyroid hormone alpha correlate with divergent properties of thyroid hormone receptor $\alpha 1$ mutant proteins. Thyroid 2017;27:973-982.

26. Kalikiri MK, Mamidala MP, Rao AN, Rajesh V. Analysis and functional characterization of sequence variations in ligand binding domain of thyroid hormone receptors in autism spectrum disorder (ASD) patients. Autism Res 2017;10:1919-1928. Epub 2017 Aug 30

27. Sun H, Chen XL, Chen T, Wu HY, Xie RR, Wang FY, Wang XY, Chen LQ. [Clinical characteristics of thyroid hormone resistance syndrome in two cases with different subtypes]. Zhonghua Er Ke Za Zhi 2017;55:953956.

28. Sun H, Wu H, Xie R, Wang F, Chen T, Chen X, Wang X, Flamant F, Chen L. New Case of Thyroid Hormone Resistance $\alpha$ Caused by a Mutation of THRA /TR $\alpha 1$. J Endocr Soc 2019;3:665-669.

29. Korkmaz O, Ozen S, Ozdemir TR, Goksen D, Darcan S. A novel thyroid hormone receptor alpha gene mutation, clinic characteristics, and follow-up findings in a patient with thyroid hormone resistance. Hormones (Athens) 2019;18:223-227. Epub 2019 Feb 12

30. Wejaphikul K, Groeneweg S, Hilhorst-Hofstee Y, Chatterjee VK, Peeters RP, Meima ME, Visser WE. Insight Into Molecular Determinants of T3 vs T4 Recognition From Mutations in Thyroid Hormone Receptor $\alpha$ and $\beta$. J Clin Endocrinol Metab 2019;104:3491-3500.

31. Wang TQ, Li CP, Zhou H, Lu T, Long SS, Ma Y, Wang Y. THRA gene mutation in a child with congenital hypothyroidism. Zhonghua Er Ke Za Zhi 2019;57:291-292.

32. le Maire A, Bouhours-Nouet N, Soamalala J, Mirebeau-Prunier D, Paloni M, Guee L, Heron D, Mignot C, Illouz F, Joubert F, Briet C, Rodien P, Bourguet W, Flamant F, Guyot R. Two novel cases of resistance to thyroid hormone due to THRA mutation. Thyroid 2020;30:1217-1221. Epub 2020 Apr 23

33. van Gucht ALM, Moran C, Meima ME, Visser WE, Chatterjee K, Visser TJ, Peeters RP. Resistance to Thyroid Hormone due to Heterozygous
Mutations in Thyroid Hormone Receptor Alpha. Curr Top Dev Biol 2017;125:337-355. Epub 2017 Mar 21

34. Moran C, Chatterjee K. Resistance to thyroid hormone $\alpha$-emerging definition of a disorder of thyroid hormone action. J Clin Endocrinol Metab 2016;101:2636-2639.

35. Refetoff S, Dumitrescu AM. Syndromes of reduced sensitivity to thyroid hormone: Genetic defects in hormone receptors, cell transporters and deiodination. Best Pract Res Clin Endocrinol Metab 2007;21:277-305.

36. Astapova I, Hollenberg AN. The in vivo role of nuclear receptor corepressors in thyroid hormone action. Biochim Biophys Acta 2013;1830:3876-3881. Epub 2012 Jul 16

37. Vella KR, Ramadoss P, Costa-E-Sousa RH, Astapova I, Ye FD, Holtz KA, Harris JC, Hollenberg AN. Thyroid hormone signaling in vivo requires a balance between coactivators and corepressors. Mol Cell Biol 2014;34:1564-1575. Epub 2014 Feb 18

38. Freudenthal B, Shetty S, Butterfield NC, Logan JG, Han CR, Zhu X, Astapova I, Hollenberg AN, Cheng SY, Bassett JHD, Williams GR. Genetic and Pharmacological Targeting of Transcriptional Repression in Resistance to Thyroid Hormone Alpha. Thyroid 2019;29:726-734. Epub 2019 Mar 14

39. Fraichard A, Chassande O, Plateroti M, Roux JP, Trouillas J, Dehay C, Legrand C, Gauthier K, Kedinger M, Malaval L, Rousset B, Samarut J. The T3R $\alpha$ gene encoding a thyroid hormone receptor is essential for post-natal development and thyroid hormone production. EMBO J $1997 ; 16: 4412-4420$.

40. Barca-Mayo O, Liao XH, Alonso M, Di Cosmo C, Hernandez A, Refetoff $\mathrm{S}$, Weiss RE. Thyroid hormone receptor $\alpha$ and regulation of type 3 deiodinase. Mol Endocrinol 2011;25:575-583. Epub 2011 Feb 3

41. Huang MP, Rodgers KA, O’Mara R, Mehta M, Abuzahra HS, Tannenbaum AD, Persons K, Holick MF, Safer JD. The thyroid hormone degrading type 3 deiodinase is the primary deiodinase active in murine epidermis. Thyroid 2011;21:1263-1268. Epub 2011 Sep 21

42. Quignodon L, Vincent S, Winter H, Samarut J, Flamant F. A point mutation in the activation function 2 domain of thyroid hormone receptor $\alpha 1$ expressed after CRE-mediated recombination partially recapitulates hypothyroidism. Mol Endocrinol 2007;21:2350-2360. Epub 2007 Jul 10

43. Bassett JH, Boyde A, Zikmund T, Evans H, Croucher PI, Zhu X, Park JW, Cheng SY, Williams GR. Thyroid hormone receptor alpha mutation causes a severe and thyroxine resistant skeletal dysplasia in female mice. Endocrinology 2014;155:3699-3712. Epub 2014 Jun 10

44. Kaneshige M, Suzuki H, Kaneshige K, Cheng J, Wimbrow H, Barlow C, Willingham MC, Cheng S. A targeted dominant negative mutation of the thyroid hormone alpha 1 receptor causes increased mortality, infertility, and dwarfism in mice. Proc Natl Acad Sci U S A 2001;98:15095-15100. Epub 2001 Dec 4

45. Bassett JH, O'Shea PJ, Sriskantharajah S, Rabier B, Boyde A, Howell PG, Weiss RE, Roux JP, Malaval L, Clement-Lacroix P, Samarut J, Chassande O, Williams GR. Thyroid hormone excess rather than thyrotropin deficiency induces osteoporosis in hyperthyroidism. Mol Endocrinol 2007;21:1095-1107. Epub 2007 Feb 27

46. Stevens DA, Harvey CB, Scott AJ, O'Shea PJ, Barnard JC, Williams AJ, Brady G, Samarut J, Chassande O, Williams GR. Thyroid hormone activates fibroblast growth factor receptor-1 in bone. Mol Endocrinol 2003;17:1751-1766. Epub 2003 Jun 12

47. O'Shea PJ, Bassett JH, Cheng SY, Williams GR. Characterization of skeletal phenotypes of $T R \alpha 1$ and $T R \alpha$ mutant mice: implications for tissue thyroid status and T3 target gene expression. Nucl Recept Signal 2006;4:11. Epub 2006 Jul 7

48. Bassett JH, Nordström K, Boyde A, Howell PG, Kelly S, Vennström B, Williams GR. Thyroid status during skeletal development determines 
adult bone structure and mineralization. Mol Endocrinol 2007;21:18931904. Epub 2007 May 8

49. Barnard JC, Williams AJ, Rabier B, Chassande O, Samarut J, Cheng SY, Bassett JH, Williams GR. Thyroid hormones regulate fibroblast growth factor receptor signaling during chondrogenesis. Endocrinology 2005; 146:5568-5580

50. Xing W, Govoni KE, Donahue LR, Kesavan C, Wergedal J, Long C, Bassett JHD, Gogakos A, Wojcicka A, Williams GR, Mohan S. Genetic evidence that thyroid hormone is indispensable for prepubertal insulinlike growth factor-I expression and bone acquisition in mice. J Bone Miner Res 2012;27:1067-1079.

51. Keane VA. Assessment of growth. In: Kliegman RM, Stanton BF, St Geme JW III, Schor NF (eds). Nelson Textbook of Pediatrics 20th ed. Philadelphia, PA, Elsevier, 2016.

52. Bernal J. Thyroid hormone receptors in brain development and function. Nat Clin Pract Metab 2007;3:249-259.

53. Tinnikov A, Nordström K, Thorén P, Kindblom JM, Malin S, Rozell B, Adams M, Rajanayagam O, Pettersson S, Ohlsson C, Chatterjee K, Vennström B. Retardation of post-natal development caused by a negatively acting thyroid hormone receptor alpha1. EMBO J 2002;21:5079-5087.

54. Itoh Y, Esaki T, Kaneshige M, Suzuki H, Cook M, Sokoloff L, Nunez $\mathrm{J}$. Brain glucose utilization in mice with a targeted mutation in the thyroid hormone alpha or beta receptor gene. Proc Natl Acad Sci U S A 2001;98:9913-9918. Epub 2001 Jul 31

55. Bernal J, Guadaño-Ferraz A. Analysis of thyroid hormone-dependent genes in the brain by in situ hybridization. Methods Mol Biol 2002;202:71-90.

56. Morte B, Manzano J, Scanlan T, Vennström B, Bernal J. Deletion of the thyroid hormone receptor alpha 1 prevents the structural alterations of the cerebellum induced by hypothyroidism. Proc Natl Acad Sci U S A 2002;99:3985-3989. Epub 2002 Mar 12

57. Wilcoxon JS, Nadolski GJ, Samarut J, Chassande O, Redei EE. Behavioral Inhibition and Impaired Spatial Learning and Memory in Hypothyroid Mice Lacking Thyroid Hormone Receptor $\alpha$. Behav Brain Res 2007;177:109-116. Epub 2006 Nov 28

58. Vennström B, Mittag J, Wallis K. Severe psychomotor and metabolic damages caused by a mutant thyroid hormone receptor alpha 1 in mice: can patients with a similar mutation be found and treated? Acta Paediatr 2008;97:1605-1610. Epub 2008 Sep 15

59. Venero C, Guadano-Ferraz A, Herrero AI, Nordström K, Manzano J, de Escobar GM, Bernal J, Vennström B. Anxiety, memory impairment, and locomotor dysfunction caused by a mutant thyroid hormone receptor $\alpha 1$ can be ameliorated by T3 treatment. Genes Dev 2005;19:21522163. Epub 2005 Aug 30

60. Wallis K, Sjögren M, van Hogerlinden M, Silberberg G, Fisahn A, Nordström K, Larsson L, Westerblad H, Morreale de Escobar G, Shupliakov O, Vennström B. Locomotor deficiencies and aberrant development of subtype-specific GABAergic interneurons caused by an unliganded thyroid hormone receptor $\alpha 1$. J Neurosci 2008;28:19041915.

61. Pilhatsch M, Winter C, Nordström K, Vennström B, Bauer M, Juckel G. Increased depressive behaviour in mice harboring the mutant thyroid hormone receptor alpha 1. Behav Brain Res 2010;214:187-192. Epub 2010 May 16

62. Bao L, Roediger J, Park S, Fu L, Shi B, Cheng SY, Shi YB. Thyroid Hormone Receptor Alpha Mutations Lead to Epithelial Defects in the Adult Intestine in a Mouse Model of Resistance to Thyroid Hormone. Thyroid 2019;29:439-448. Epub 2019 Jan 25

63. Pantos C, Xinaris C, Mourouzis I, Perimenis P, Politi E, Spanou D, Cokkinos DV. Thyroid hormone receptor alpha 1: a switch to cardiac cell “metamorphosis"? J Physiol Pharmacol 2008;59:253-269.
64. Mittag J. Cardiovascular consequences of a mutant thyroid hormone receptor $\alpha 1$. Eur J Endocrinol 2010;6:51-54.

65. Makino A, Wang H, Scott BT, Yuan JX, Dillmann WH. Thyroid hormone receptor- $\alpha$ and vascular function. Am J Physiol Cell Physiol 2012;302:1346-1352. Epub 2012 Feb 8

66. Marrif H, Schifman A, Stepanyan Z, Gillis MA, Calderone A, Weiss RE, Samarut J, Silva JE. Temperature homeostasis in transgenic mice lacking thyroid hormone receptor-alpha gene products. Endocrinology 2005;146:2872-2884. Epub 2005 Apr 21

67. Sjögren M, Alkemade A, Mittag J, Nordström K, Katz A, Rozell B, Westerblad H, Arner A, Vennström B. Hypermetabolism in mice caused by the central action of an unliganded thyroid hormone receptor alpha1. EMBO J 2007;26:4535-4545. Epub 2007 Oct 11

68. Fein HG, Rivlin RS. Anemia in thyroid diseases. Med Clin North Am 1975;59:1133-1145.

69. Kendrick TS, Payne CJ, Epis MR, Schneider JR, Leedman PJ, Klinken SP, Ingley E. Erythroid defects in TRalpha-/- mice. Blood 2008;111:32453248. Epub 2008 Jan 18

70. Angelin-Duclos C, Domenget C, Kolbus A, Beug H, Jurdic P, Samarut J. Thyroid hormone T3 acting through the thyroid hormone receptor is necessary for implementation of erythropoiesis in the neonatal spleen environment in the mouse. Development 2005;132:925-934. Epub 2005 Jan 26

71. van Gucht ALM, Meima ME, Moran C, Agostini M, Tylki-Szymanska A, Krajewska MW, Chrzanowska K, Efthymiadou A, Chrysis D, Demir K, Visser WE, Visser TJ, Chatterjee K, van Dijk TB, Peeters RP. Anemia in Patients with Resistance to Thyroid Hormone $\alpha$ : A Role for Thyroid Hormone Receptor $\alpha$ in Human Erythropoiesis. J Clin Endocrinol Metab 2017;102:3517-3525.

72. van der Spek AH, Surovtseva OV, Aan S, Tool ATJ, van de Geer A, Demir K, van Gucht ALM, van Trotsenburg ASP, van den Berg TK, Fliers E, Boelen A. Increased circulating interleukin-8 in patients with resistance to thyroid hormone receptor $\alpha$. Endocr Connect 2017;6:731-740.

73. Goldman J, Matz R, Mortimer R, Freeman R. High elevations of creatine phosphokinase in hypothyroidism. An isoenzyme analysis. JAMA 1977;238:325-326.

74. Boumaza H, Markossian S, Busi B, Rautureau GJP, Gauthier K, ElenaHerrmann B, Flamant F. Metabolomic Profiling of Body Fluids in Mouse Models Demonstrates that Nuclear Magnetic Resonance Is a Putative Diagnostic Tool for the Presence of Thyroid Hormone Receptor $\alpha 1$ Mutations. Thyroid 2019;29:1327-1335. Epub 2019 Aug 28

75. Persani L, Brabant G, Dattani M, Bonomi M, Feldt-Rasmussen U, Fliers E, Gruters A, Maiter D, Schoenmakers N, van Trotsenburg ASP. 2018 European Thyroid Association (ETA) Guidelines on the Diagnosis and Management of Central Hypothyroidism. Eur Thyroid J 2018;7:225237. Epub 2018 Jul 19

76. Allan W, Herndon CN, Dudley FC. Some examples of the inheritance of mental deficiency: apparently sex-linked idiocy and microcephaly. Am J Ment Defic 1944;48:325-334.

77. Schwartz CE, Stevenson RE. The MCT8 thyroid hormone transporter and Allan-Herndon-Dudley syndrome. Best Pract Res Clin Endocrinol Metab 2007;21:307-321.

78. Anık A, Kersseboom S, Demir K, Catlı G, Yiş U, Böber E, van Mullem A, van Herebeek RE, Hiz S, Abacı A, Visser TJ. Psychomotor retardation caused by a defective thyroid hormone transporter: report of two families with different MCT8 mutations. Horm Res Paediatr 2014;82:261-271. Epub 2014 Sep 18

79. Herzovich V, Vaiani E, Marino R, Dratler G, Lazzati JM, Tilitzky S, Ramirez P, Iorcansky S, Rivarola MA, Belgorosky A. Unexpected 
peripheral markers of thyroid function in a patient with a novel mutation of the MCT8 thyroid hormone transporter gene. Horm Res 2007;67:1-6. Epub 2006 Sep 15

80. Friesema EC, Grueters A, Biebermann H, Krude H, von Moers A, Reeser M, Barrett TG, Mancilla EE, Svensson J, Kester MH, Kuiper GG, Balkassmi S, Uitterlinden AG, Koehrle J, Rodien P, Halestrap AP, Visser T. Association between mutations in a thyroid hormone transporter and severe X-linked psychomotor retardation. Lancet 2004;364:14351437.

81. Ocasio CA, Scanlan TS. Design and characterization of a thyroid hormone receptor alpha (TRalpha)-specific agonist. ACS Chem Biol 2006; 1:585-593.

82. Fozzatti L, Kim DW, Park JW, Willingham MC, Hollenberg AN, Cheng SY. Nuclear receptor corepressor (NCOR1) regulates in vivo actions of a mutated thyroid hormone receptor alpha. Proc Natl Acad Sci USA 2013;110:7850-7855. Epub 2013 Apr 22

83. Kim DW, Park JW, Willingham MC, Cheng SY. A histone deacetylase inhibitor improves hypothyroidism caused by a TR $\alpha 1$ mutant. Hum Mol Genet 2014;23:2651-2664. Epub 2013 Dec 30

84. Tan J, Cang S, Ma Y, Petrillo RL, Liu D. Novel histone deacetylase inhibitors in clinical trials as anti-cancer agents. J Hematol Oncol 2010;3:5.

85. Wit JM, Kamp GA, Oostdijk W; on behalf of the Dutch Working Group on Triage and Diagnosis of Growth Disorders in Children. Towards a Rational and Efficient Diagnostic Approach in Children Referred for Growth Failure to the General Paediatrician. Horm Res Paediatr 2019;91:223-240. Epub 2019 Jun 13 